\title{
Pertanggungjawaban Pidana Terhadap Perusahaan yang Lalai Mendaftarkan Pekerjanya sebagai Peserta BPJS Ketenagakerjaan
}

\section{Indrawati ${ }^{1}$, Tumiar Rohana Simanjuntak ${ }^{2}$}

1 Indrawati; Fakultas Hukum Universitas Merdeka Malang; Jl. Terusan Dieng No. 62 - 64; Malang; 65115; Jawa Timur; Indonesia.

2 Tumiar Rohana Simanjuntak; Magister Ilmu Hukum Universitas Merdeka Malang; Jl. Terusan Dieng No. 62 - 64; Malang; 65115; Jawa Timur; Indonesia.

\begin{tabular}{l} 
A R T I C L E I N F O \\
\hline Article history: \\
Received 2019-05-09 \\
Received in revised form \\
2019-06-19s \\
Accepted 2019-07-01 \\
\hline
\end{tabular}

Kata kunci:

Tanggung Jawab Pidana, Kelalaian, Pekerja.

Keywords:

Criminal Liability, Negligence,

Workers.

\section{Citation:}

Indrawati, I., \& Simanjuntak, T. (2019). Pertanggungjawaban Pidana Terhadap Perusahaan yang Lalai Mendaftarkan Pekerjanya SebagaiPesertaBPJS Ketenagakerjaan. Jurnal Cakrawala Hukum, 10(1). doi:10.26905/idjch.v10i1.3180
Corresponding Author:

Indrawati

E-mail address: indrawati@unmer.ac.id DOI: https://doi.org/10.26905/idjch.v10i1.3180.

\section{Abstrak}

Penelitian ini membahas tanggung jawab pidana terhadap perusahaan yang lalai mendaftarkan tenaga mereka sebagai tenaga kerja BPJS peserta. Jaminan sosial sangat penting dimiliki oleh seluruh pekerja Indonesia karena risiko sosial ekonomi itu bisa terjadi kepada siapa saja, dimana saja dan terhadap siapa saja. Jenis penelitian hukum yang digunakan dalam penelitian ini adalah penelitian normatif. Hasil dan pembahasan dari penelitian yang dilakukan dimana PT. Prakarsa Tani Sejati ini telah melakukan suatu kesalahan berupa kelalaian atau kealpaan dari pihak perusahaan tersebut yang tidak membayarakan iuran BPJS Ketenagakerjaan pekerjanya dan terdapat beberapa tenaga kerja yang tidak didaftarkan sebagai peserta BPJS Ketenagakerjaan. Hal tersebut telah mendapat putusan pengadilan yang menghukum perusahaan yang mengakibatkan hak-hak dari pekerja yang tidak dapat dipenuhi. Melihat putusan yang telah ditetapkan oleh hakim tidak terdapat hukuman pidana, dalam putusan hakim kurang memberikan efek jera terhadap perusahaan. Ketentuan UU Ketenagakerjaan BPJS saat ini ditambahkan penerapan sanksi hukuman penjara, sehingga di masa depan dapat memberikan efek jera pada perusahaan yang gagal mendaftarkan tenaga mereka sebagai peserta BPJS Ketenagakerjaan.

\begin{abstract}
This study discusses criminal liability towards companies that fail to register their workers as participating BPJS workers. Social security is very important for all Indonesian workers to have because socioeconomic risks can occur to anyone, anywhere and to anyone. The type of legal research used in this study is normative research. Results and discussion of research conducted where PT. This True Farmer Initiative has made a mistake in the form of negligence or negligence from the company that does not pay BPJS Employment contributions to workers and there are some workers who are not registered as BPJS Employment participants. This has
\end{abstract}


been received by a court ruling punishing the company which resulted in the rights of the workers who could not be fulfilled. Seeing the decision that has been determined by the judge there is no criminal sentence, the judge's decision does not provide a deterrent effect on the company. The provisions of the BPJS Employment Act currently added the application of imprisonment sanctions, so that in the future it can provide a deterrent effect on companies that fail to register their workers as BPJS Employment participants.

\section{Latar Belakang}

Jaminan sosial merupakan hak seluruh warga negara yang sampai saat ini masih mencari formula dan bentuknya, sehingga belum sepenuhnya dapat dinikmati seluruh lapisan masyarakat tidak terkecuali kaum buruh. Penyelenggaraan program jaminan sosial merupakan salah satu tanggung jawab dan kewajiban negara untuk memberikan perlindungan sosial ekonomi kepada masyarakat. Sesuai dengan kondisi kemampuan keuangan Negara. Indonesia seperti halnya negara berkembang lainnya, mengembangkan program jaminan sosial berdasarkan funded social security, yaitu jaminan sosial yang didanai oleh peserta.

Jaminan sosial sangat penting dimiliki oleh seluruh pekerja Indonesia karena risiko sosial ekonomi itu bisa terjadi kepada siapa saja, dimana saja dan terhadap siapa saja. Risiko sosial ekonomi itu seperti kecelakaan dan kematian, sehingga perlu ada satu alat pengaman, supaya kalau terjadi risiko sosial ekonomi tadi tidak akan mengganggu kesejahteraannya secara drastis. Dengan kata lain, jaminan sosial kita perlukan agar seseorang tidak langsung jatuh miskin mendadak pada saat mengalami suatu musibah (kecelakaan) dan kematian. Pekerja ini tulang punggung keluarga, suatu hari mengalami kecelakaan, tidak bisa bekerja, tidak mendapatkan penghasilan, lantas bagaimana untuk menghadapi keluarga dan memenuhi kebutuhan lain. Esensi atau filosofi jaminan sosial ini adalah memberikan proteksi agar masyarakat pekerja ini tetap dapat memenuhi kebutuhan hidup dasar yang layak terpenuhi kalau terjadi musibah kecelakaan, tidak bekerja.

Jaminan sosial ini juga merupakan hak dari masyarakat perkerja. Hak ini dijamin Undang Undang Dasar Republik Indonesia tahun 1945 (UUD 1945) maupun Undang-undang Sitem Jaminan Sosial atau Undang-undang BPJS Ketenagakerjaan. Bahkan, diratifikasi juga dalam HAM bahwa semua orang memiliki hak mendapatkan jaminan sosial ketenagakerjaan. BPJS Ketenagakerjaan Indonesia ini pendanaannya dari masyarakat. Jadi, dari masyarakat, oleh masyarakat, untuk masyarakat.

Tidak didanai oleh negara atau APBN, tetapi selffounding. Konsekuensinya, semua peseta harus ada konstribusi iuran. Harus membayar iuran. Tantangannya, bagaimana masyarakat pekerja ini bisa mengiur dan mau menjadi peserta. Jaminan sosial ini dibuat bukan karena kewajiban semata, tapi juga berdasarkan kebutuhan. Manfaatnya luar biasa untuk bisa melindungi para pekerja bila terjadi musibah atau memasuki usia yang tidak produktif.

Akibat dari tidak didaftarkan BPJS Ketenagakerjaan, maka ada sanksinya yaitu mulai dari sanksi teguran, administratif, sanksi denda, sanksi cabut izin atau sanksi tidak mendapatkan pelayanan hukum. Ada sanksi lain, yaitu bila pekerjanya mengalami musibah, tapi tidak di cover maka pekerja ini bisa mendapatkan haknya, seperti yang kalau dia didaftarkan di dalam BPJS Ketenagakerjaan.

Jika perusahaan tidak mendaftarkan karyawannya kemudian karyawannya mengalami kece- 
lakaan atau meninggal maka perusahaan ini wajib untuk memberikan hak karyawan sama persis atau minimal sama, jika dia didaftarkan di BPJS Ketenagakerjaan. Jika seperti ini, akan menimbulkan kerugian yang tidak terukur. Sebab, penggantian yang diberikan oleh BPJS Ketenagakerjaan ini sangat besar. Misalnya, jika pekerja mengalami kecelakaan kerja, butuh perawatan di rumah sakit, BPJS Ketenagakerjaan akan membiayai, menanggung seluruh biaya itu sampai sembuh (unlimited). Jika sampai dalam enam bulan, karyawan tersebut tidak bisa bekerja, kemudian tidak dapat gaji maka gajinya tetap akan dibayar oleh BPJS Ketenagakerjaan, namanya ada santunan pengganti upah.

Selama enam bulan pertama dibayar penuh. Enam bulan berikutnya 75 persen, enam bulan berikutnya 50 persen, dan seterusnya. Jika sampai cacat, ada santunan uang tunai. Si pekerja bisa kembali bekerja, yaitu melalui program yang mendidik, latih atau training. Hal ini kalau dikalkulasi dalam bentuk uang, maka biayanya sangat besar. Jika ini ditagihkan pada perusahaan maka perusahaan bisa kolaps. Banyak sekali kasus, yang mana pekerjanya meninggal dunia, perusahaannya tidak mengcover, ahli warisnya menuntut kepada perusahaan tersebut. Keputusan pengadilan jelas, karena memang undang-undang peraturan hukumnya sudah ada. (Oktavianus, 2018)

Saat ini masih terdapat banyak tenaga kerja yang belum terdaftarkan menjadi peserta BPJS Ketenagakerjaan, hal ini disebabkan karena adanya kewajiban iuran yang mana sebesar $4,24 \%$ dari total upah untuk tiga program yang wajib diikuti berdasarkan ketentuan undang-undang merupakan tanggung jawab dari pemberi kerja dan 2\% dari total upah merupakan kewajiban yang dipotongkan dari penghasilan tenaga kerjanya setiap bulannya, sehingga total yang dibayarkan kepada BPJS Ketenagakerjaan sejumlah 6,24\% dari total upah.

Hal inilah yang menyebabkan pihak pemberi kerja tidak mendaftarkan keseluruhan tenaga kerjanya sebagai perserta BPJS Ketenagakerjaan, untuk menghindari kewajiban dan mengurangi pengeluaran keuangan perusahaan, dimana telah dijelaskan sebelumnya untuk sanksi ketidak patuhan perusahaan yang tidak mendaftarkan tenagakerjanya dikenakan sanksi teguran, administratif, sanksi denda, sanksi cabut izin atau sanksi tidak mendapatkan pelayanan hukum, dimana saat ini untuk sanksi pidana terhadap perusahaan belum memiliki aturan yang pasti, apabila terdapat unsur pidana dalam ketidakpatuhan dan kelalaian perusahaan mendaftarkan tenaga kerjanya menjadi peserta BPJS Ketenagakerjaan akankah adanya peraturan yang pasti dalam penerapan sanksi pidana dalam undang-undang terkait penerapan sanksi terhadap perusahaan yang lalai dan tidak patuh dalam mendaftarkan tenagakerjanya sebagai peserta BPJS Ketenagakerjaan, yang mana telah tertuang dalam undang-undang bahwasanya perusahaan wajib mendaftarkan tenagakerjanya sebagai peserta BPJS Ketenagakerjaan terhadap pekerja yang menerima upah dari pemberi kerja atau perusahaan.

\section{Metode}

Jenis penelitian hukum normatif dengan teknik penelusuran bahan hukum ini dilakukan dengan cara membaca, mengkaji, dan membuat catatan dari buku-buku, peraturan perundang-undangan, dokumen, serta tulisan-tulisan yang berhubungan dengan masalah yang menjadi objek penelitian, menganalisis putusan.

\section{Pembahasan}

\subsection{Pertanggungjawaban Pidana Terhadap Per- usahaan yang Lalai Mendaftakan Pekerjanya Sebagai Peserta BPJS Ketenagakerjaan}

Ketentuan pidana sebagai suatu bentuk sanksi hukum merupakan ketentuan yang bertujuan untuk menjamin kepatuhan masyarakat kepada peraturan perundang-undangan di bidang jaminan sosial, di samping ketentuan mengenai sanksi 
administratif. Menjamin terpenuhinya asas, tujuan, dan prinsip sistem jaminan sosial nasional. Sesuai dengan kekuasaan yang dimilikinya, pemerintah secara bijaksana dapat menyesuaikan apa yang ditentukan sebagai perbuatan pidana dengan perasaan hukum yang hidup dalam masyarakat, dimana penentuan tersebut akan dapat dipandang sebagai jalan yang utama untuk mencegah dilarangnya larangan-larangan. (Mulijanto, 2002)

Pendaftaran tenagakerja dalam program BPJS Ketenagakerjaan ini merupakan hal yang wajib diikuti oleh pihak pemberi kerja, untuk mengikutsertakan seluruh tenaga kerjanya dalam program BPJS Ketenagakerjaan ini, yang telah diatur pada undang-undang nomor 24 tahun 2011 tentang Badan Penyelenggara Jaminan Sosial.

Pasal 15 ayat 1 Undang-Undang Republik Indonesia Nomor 24 Tahun 2011 Tentang Badan Penyelenggra Jaminan Sosial menyatakan bahwa "Pemberi kerja secara bertahap wajib mendaftarkan dirinya dan pekerjanya sebagai peserta kepada BPJS sesuai dengan program Jaminan Sosial yang diikuti".

Akan tetapi terkait pasal 15 ayat 1 tersebut jika tidak dilaksanakan oleh pihak pemberi kerja akan dikenakan sanksi administratif sebagaimana dimaksud dalam Pasal 17 ayat 1 dan 2 menyatakan “ (1) Pemberi kerja selain penyelenggara negara yang tidak melaksanakan ketentuan sebagaimana dimaksud dalam pasal 15 ayat (1) dan ayat (2), dan setiap orang yang tidak melaksanakan ketentuan sebagaimana dimaksud dalam pasal 16 dikenakan sanksi administratif; (2) Sanksi administratif sebagaimana dimaksud pada ayat (1) dapat berupa: a. Teguran tertulis; b. Denda; dan/atau c. Tidak mendapatkan pelayanan publik tertentu.

Jika dibandingkan dengan peraturan PT. Jamsostek (Persero) sebelumnya Undang-Undang Republik Indonesia Nomor 3 Tahun 1992 Tentang Jaminan Sosial Tenaga Kerja, terdapat unsur sanksi pidana terhadap perusahaan yang tidak mendaftarkan tenaga kerjanya sebagai peserta BPJS Ketenagakerjaan.
Pasal 3 ayat 1 dan 2 menyatakan (1) untuk memberikan perlindungan kepada tenaga kerja diselenggarakan program jaminan sosial tenaga kerja yang pengelolaanya dapat dilaksankan dengan mekanisme asuransi; (2) Setiap tenaga kerja berhak atas jaminan sosial tenaga kerja.

Pasal 4 ayat 1 menyatakan Program Jaminan Sosial tenaga kerja sebagaimana dimaksud dalam pasal 3 wajib dilakukan oleh setiap perusahaan bagi tenaga kerja yang melakukan pekerjaan didalam hubungan kerja sesuai dengn ketentuan UndangUndang ini.

Pasal 29 ayat 1 dan ayat 2 menyatakan (1) Barang siapa tidak memenuhi kewajiban sebagaimana dimaksud dalam pasal 4 ayat (1); Pasal 10 ayat (1), ayat (2), dan ayat (3); pasal 18 ayat (1), ayat (2), ayat (3), ayat (4), dan ayat (5); pasal 19 ayat (2); pasal 22 yat (1); dan pasal 26, diancam dengan hukuman kurungan selama-lamanya 6 (enam) bulan atau denda setinggi-tingginya Rp. 50.000.000,- (lima puluh juta rupiah); (2) Dalam hal pengulangan tindak pidana sebagaimana dimaksud dalam ayat (1) untuk kedua kalinya atau lebih, setelah putusan akhir telah memperoleh kekuatan hukum tetap, maka pelanggaran tersebut dipidana kurungan selama-lamanya 8 (delapan) bulan.

Dengan demikian jika melihat penerapan sanksi yang diberikan terhadap pihak perusahaan yang tidak mendaftarkan tenagakerjanya sebagai peserta BPJS Ketenagakerjaan, kurang memberikan efek penenkanan terhadap peusahana yang tidak mendaftarkan tenagakerjanya sebagai peserta BPJS Ketenagakerjaan. Dan akan mengakibatkan banyaknya perusahaan yang tidak mendaftarkan seluruh tenagakerjanya untuk mengurangi biaya yang akan dikeluarkan oleh pihak perusahaan, dikarenakan tidak adanya ancaman hukuman sanksi pidana.

Berkaitan dengan penelitian yang dilakukan oleh penulis ini, PT. Prakarsa Tani Sejati yang merupakan pelaku usaha yang berbentuk badan hukum (korporasi) bergerak dalam bidang indus- 
tri yang mana mempekerjakan tenaga kerja salah satunya bernama Almarhumah Sulistia, dimana pada saat menjabat terakhir sebagai operator timbangan (Weigh Brige) di pabrik, sebelum almarhumah meninggal dunia pernah dirawat di Rumah Sakit Umum Dr. Soedarso Pontianak, selama beliau dirawat di rumah sakit dari pihak perusahaan PT. Prakarsa Tani Sejati tidak pernah menjenguk, tidak memberikan biaya pengobatan ataupun membuat laporan perihal sakit kepada pihak Badan Penyelenggara Jaminan Sosial Ketenagakerjaan Cabang Kalimantan Barat yang merupakan kewajiban dari pihak perusahaan.

Selain itu juga, pihak perusahaan tidak pernah memberikan ganti rugi biaya pengobatan bahkan sampai dengan meninggal dunia pun tidak ada memberikan santunan sama sekali, justru santunan hanya didapat dari pihak BPJS Ketenagakerjaan hanya berupa Jaminan Hari Tua, Jaminan Kematian, serta santunan berkala. Sedangkan Jaminan Pemeliharaan Kesehatan dan Jaminan Kecelakaan Kerja tidak dibayarkan oleh pihak BPJS Ketenagakerjaan dikarenakan masih terdapatnya tunggakan iuran yang belum dibayarkan oleh pihak perusahan PT. Prakarsa Tani Sejati, yang mana hal tersebut merupakan aturan dari BPJS Ketenagakerjaan jika terdapat tunggakan iuran dari pihak perusahaan, dan terdapat beberapa tenaga keja yang belum terdaftar sebagai peserta BPJS Ketenagakerjaan, maka untuk proses pengajuan klaim menunggu tunggakan iuran dibayarkan terlebih dahulu, kemudian barulah bisa dilakukan pencairan klaim santunan jaminan.

Berdasarkan teori pertanggungjawaban pidana menurut pendapat Cristina de Maglie di atas, tindak pidana dan kesalahan seseorang yang bertindak untuk dan atas nama korporasi secara otomatis juga merupakan tindak pidana dan kesalahan korporasi, dengan syarat: 1. Agen dari korporasi melakukan kejahatan; dalam hal ini kejahatan perbuatan atau tindakan secara serampangan yang dilakukan oleh a high managerial agent, yaitu orang yang bertanggungjawab bahwa perbuatanya dapat diasumsikan mewakili kebijakan korporasi. Seperti kasus PT. Prakarsa Tani Sejati ini, dimana perusahaan melakukan kejahatan tidak membayarkan iuran perusahaan kepada BPJS Ketenagakejaan; 2. Agen dari korporasi ketika melakukan kejahatan tersebut dalam batas pekerjaannya; hal ini berarti bahwa apabila korporasi melakukan tindak pidana dan hal tersebut berada dalam ruang lingkup pekerjaanya maka korporasi dapat dipetanggungjawabkan dalam hukum pidana.

Seperti pada kasus PT. Prakarsa Tani Sejati, dalam hal ini kejahatan yang dilakukan oleh pihak korporasi dalam hal batasan pekerjaan, tidak dilua hal pekerjaann yang mana meugikan hak-hak para pekerja dengan tidak membayarkan iuran yang sudah dipotong dari gaji para pekerja kepada pihak BPJS Ketenagakejaan; 3. Kejahatan yang dilakukan agen dari korporasi tersebut bertujuan untuk menguntungkan korporasi; dalam hal ini kejahatan yang dilakukan oleh pihak korporasi baik sengaja ataupun tidak sengaja yang akan diketahui dari dampak kejahatan yang dilakukan yang bertujuan untuk menguntungkan pihak korporasi, seperti kasus PT. Prakarsa Tani Sejati, yang mana pihak perusahaan dalam kesadaranya dengan sengaja tidak membayarkan iuran BPJS Ketenagakerjaan para pekerjanya kepada pihak BPJS Ketenagakerjaan, dimana hal ini bertujuan untuk mengurangi anggaran biaya perusahaan dengan cara tidak membayarkan iuran BPJS Ketenagakerjaan dan tidak mendaftarkan keseluruhan pekerjanya untuk mengurangi biaya dari perusahaan.

Kasus PT. Prakarsa Tani Sejati ini dimana pihak perusahaan lalai dalam hal pembayaran iuran BPJS Ketenagakerjaan, dalam kasus ini juga terlihat bahwa pihak perusahaan telah memenuhi unsur kejahatan, dilakuakan kejahatan tersebut dalam hal pekerjaanya, dan yang bertujuan untuk menguntungkan korporasi, dimana terdapat tunggakan iuran yang tidak dibayarkan oleh pihak perusahaan kepada BPJS Ketenagakerjaan dalam hal ini terdapat 
unsur kelalaian atau kesengajaan dari pihak perusahaan yang tidak membayarkan tunggakan iuran perusahaan, dimana tenaga kerja setiap bulannya menerima upah dan dipotong sebesar $2 \%$ untuk pembayaran iuran BPJS Ketenagakerjaanya.

Dikarenakan, adanya tunggakan iuran sehingga pekerja yang mau mengklaimkan santunan tidak dapat diproses sebelum tunggakan iuran tersebut dibayarkan terlebih dahulu. Jadi, terlihat bahwa pertanggungjawaban pidana terhadap perusahaan yang lalai dalam mendaftarakan tenagakerjanya sebagai peserta BPJS Ketenagakejaan memenuhi unsur pidana, namun pada undangundang nomor 24 tahun 2011 tentang Badan Penyelenggaraan Jaminan Sosial terkait penerapan sanksi terhadap perusahaan yang lalai tersebut tidak diterapkan sanksi pidana, akan tetapi pada peraturan sebelunya undang-undang nomor3 tahun 1992 entang Jaminan Sosial Tenagakerja telah diatur penerapan sanki pidana terhadap perusahaan yang lalai dalam mendaftarkan tenagakerjanya sebagai peserta BPJS Ketenagakerjaan.

\subsection{Sanksi Pidana yang Bisa Diterapkan Ter- hadap Perusahaan yang Lalai Mendaftarkan Pekerjanya Sebagai Peserta BPJS Ketenaga- kerjaan.}

Kepesertaan pekerja dalam sistem jaminan sosial adalah bersifat wajib, Undang-Undang Sistem Jaminan Sosial Nasional. (Wijaya, 2017) Pasal 13 ayat (1) Menyatakan bahwa "Menentukan bahwa pemberi kerja secara bertahap wajib mendaftarkan dirinya dan pekerjanya sebagai peserta kepada Badan Penyelenggara Jaminan Sosial, sesuai dengan program jaminan sosial yang diikuti".

Undang-Undang Republik Indonesia Nomor 24 Tahun 2011 Tentang Badan Penyelenggaraan Jaminan Sosial saat ini, terhadap perusahaan wajib untuk mendaftarkan tenagakerjanya dalam program BPJS Ketenagakerjaan. Pasal 15 ayat 1 menyatakan bahwa "Pemberi kerja secara bertahap wajib mendaftarkan dirinya dan pekerjanya sebagai peserta kepada BPJS sesuai dengan program Jaminan Sosial yang diikuti". Akan tetapi terkait pasal 15 ayat 1 tersebut jika tidak dilaksanakan oleh pihak pemberi kerja akan dikenakan sanksi administratif sebagaimana dimaksud dalam Undang-Undang Republik Indonesia Nomor 24 Tahun 2011 Tentang BPJS Ketenagakerjaan.

Pasal 17 ayat 1 dan 2 menyatakan (1) Pemberi kerja selain penyelenggara negara yang tidak melaksanakan ketentuan sebagaimana dimaksud dalam pasal 15 ayat (1) dan ayat (2), dan setiap orang yang tidak melaksanakan ketentuan sebagaimana dimaksud dalam pasal 16 dikenakan sanksi administratif. (2) Sanksi administratif sebagaimana dimaksud pada ayat (1) dapat berupa: a. Teguran tertulis; b. Denda; dan/atau c. Tidak mendapatkan pelayanan publik tertentu.

Berdasarkan penelitian yang dilakukan dimana PT. Prakarsa Tani Sejati ini telah melakukan suatu kesalahan berupa kelalaian atau kealpaan dari pihak perusahaan tersebut yang mana tidak membayarakan iuran BPJS Ketenagakerjaan para pekerjanya dan terdapat beberapa tenaga kerja yang tidak didaftarkan sebagai peserta BPJS Ketenagakerjaan, yang mana hal tersebut mengakibatkan hak-hak dari pekerja yang tidak dapat dipenuhi, melihat putusan yang ditetapkan oleh hakim tidak terdapat hukuman pidana, dalam putusan tersebut yang mana kurang memberikan efek jera terhadap perusahaan, pada putusannya menghukum tergugat untuk membayarkan ganti rugi terhadap pekerja yang seharusnya dapat dibayarkan oleh BPJS Ketenagakerjaan, dan menghukum tergugat untuk membayarkan uang pesangon kepada ahli waris, serta membayarkan seluruh biaya pengobatan dan kekurangan upah tenagakerja secara tunai.

Sanksi pidana yang diberikan kepada PT. Prakarsa Tani Sejati. Sehingga, mengabkibatkan selain dari kasus PT. Prakarsa Tani Sejati ini, banyak juga perusahaan-perusahaan diluar sana yang dengan 
sengaja tidak mendaftrakan tenagakerjanya sebagai perserta BPJS Ketenagakerjaan, atau hanya mendaftarkan sebagian tenagakerjanya, hanya untuk sekedar memenuhi persaratan wajib mendatarkan tenagakerjanya, kelalaian perusahaan tersebut dilakukan dalam keadaan sadar dan telah mengetahui manfaat dan resiko yang dihadapi jika tidak mendaftarkan tenagakerjanya sebagai peserta BPJS Ketenagakerjaan, yang mana dilakukan untuk mengurangi biaya perusahaan yang akan digunakan untuk pembayaran iuran BPJS Ketenagakerjaan tersebut.

Menurut Peraturan Pemerintah (PP) nomor 26 tahun 2015 terkait iuran perusahaan dimana untuk rate Jaminan Kecelakaan Kerja (JKK) sebesar 0,24\%-1.74\% merupakan tanggungjawab dari pihak perusahaan, untuk iuran Jaminan Kematian (JKM) sebesar $0,3 \%$ dari total upah yang dilaporkan, iuran Jaminan Hari Tua (JHT) sebesar 5,7\% dimana sebesar $2 \%$ dipotong dari gaji karyawn dan 3,7\% merupakan subsidi dari perusahaan.hal inilah yang mengakibatkan perusahaan yang denag sengaja tidak mendaftarkan tenagakerjanya, karena mengurangi cost dari pihak perusahaan. Melihat banyaknya kasus yang terjadi dalam kelalaian pihak perusahaan yg mengakibatkan ruginya para tenaga kerja, agar kedepanya dilakukan revisi penambahan sanki pidana kedalam undangundang BPJS Ketenagakerjaan untuk penerapan sanki Pidana.

Berdasarakan teori kepastian menurut Apeldoorn dan teori kebijakan legislatif menurut A. Mulder, hukum mempunyai dua segi, pertama mengenai soal dapat dibentuknya (bepaalbaarheid) hukum dalam hal-hal yang konkret. Dan seberapa jauh ketentuan-ketentuan pidana yang berlaku perlu diubah atau diperbaharui. Dalam hal ini, penulis mengharapakan agar pada undang-undang nomor 24 tahun 2011 tentang Badan Penyelanggara Jaminan Sosial dan PP nomor 86 tahun 2013 tentang tata cara pengenaan sanksi administratif kepada pemberi kerja, yang mengatur terkait penerapan sanksi agar ditambahakanya pasal yang mengatur sanksi pidana. Rekomendasi dari penulis, yaitu undang-undang yang pernah berlaku sebelumnya nomor 3 tahun 1992 tentang Jaminan Sosial Tenaga kerja.

Pasal 29 ayat 1 menyatakan bahwa "Barangsiapa tidak memenuhi kewajiban sebagaimana dimaksud dalam pasal 4 ayat (1); pasal 10 ayat (1), ayat (2), dan ayat (3), pasal 18 ayat (1), ayat (2), ayat (3), ayat (4), dan ayat (5); pasal 19 ayat (2); pasal 22 ayat (1); dan psal 26, diancam dengan hukuman kurungan selama-lamanya 6 (enam) bulan atau denda setinggi-tingginya Rp. 50.000.000,- (lima puluh juta rupiah)".

Menurut pendapat penulis agar pasal tersebut diatas dapat dicantumkan pada undangundang nomor 24 tahun 2011 tentang Badan Penyelenggara Jaminan Sosial terkait penerapan sanksi yang diterapkan terhadap perusahaan yang lalai mendaftarkan tenagakerjanya sebagai peserta BPJS Ketenagakerjaan. Sehingga, harapan kedepanya agar kasus-kasus yang terjadi lagi dapat diproses dengan menerapkan sanksi pidana. Jadi, kepada bada legislatif (DPR) pusat sebagai pembentuk undang-undang agar pada pasal 29 ayat (1) undang-unang nomor 3 tahun 1992 tentang Jaminan Sosial Tenaga Kerja tersebut diatas agar ditambahkan pada undang-undang nomor 24 tahun 2011 tentang Badan Penyelenggaraan Jaminana Sosial, sehingga apabila kedepanya nanti ditemukan adanya kasus ketenagakerjaan dapat diproses baik secara hukum pidana maupun hukum administrasi.

\section{Simpulan}

Pertanggungjawaban Pidana Terhadap Perusahan Yang Lalai Mendaftarkan Pekerjanya Sebagai Peserta BPJS Ketenagakejaan, dapat diwujudkan dengan: a. Penerapan sanksi terhadap perusahaan yang lalai mendaftarkan tenaga kerjanya sebagai peserta BPJS Ketenagakerjaan saat ini pada 
undang-undang nomor 24 tahun 2011 tentang Badan Penyelenggara Jaminan Sosial. Pasal 15 ayat 1 menyatakan bahwa "Pemberi kerja secara bertahap wajib mendaftarkan dirinya dan pekerjanya sebagai peserta kepada BPJS sesuai dengan program Jaminan Sosial yang diikuti". Akan tetapi terkait pasal 15 ayat 1 tersebut jika tidak dilaksanakan oleh pihak pemberi kerja akan dikenakan sanksi administratif sebagaimana dimaksud dalam undangundang BPJS Ketenagakerjaan nomor 24 tahun 2011.

Perkara PT. Prakarsa Tani Sejati tahun 2015 yang merupakan pelaku usaha yang berbentuk badan hukum (korporasi) bergerak dalam bidang industri yang mana mempekerjakan tenaga kerja salah satunya bernama Almarhumah Sulistia, dimana pada saat menjabat terakhir sebagai operator timbangan (Weigh Brige) di pabrik, sebelum almarhumah meninggal dunia pernah dirawat di Rumah Sakit Umum Dr. Soedarso Pontianak, selama beliau dirawat di rumah sakit dari pihak perusahaan PT. Prakarsa Tani Sejati tidak pernah menjenguk, tidak memberikan biaya pengobatan ataupun membuat laporan perihal sakit kepada pihak Badan Penyelenggara Jaminan Sosial Ketenagakerjaan Cabang Kalimantan Barat yang merupakan kewajiban dari pihak perusahaan.

Selain itu juga, pihak perusahaan tidak pernah memberikan ganti rugi biaya pengobatan bahkan sampai dengan meninggal dunia pun tidak ada memberikan santunan sama sekali, justru santunan hanya didapat dari pihak BPJS Ketenagakerjaan hanya berupa Jaminan Hari Tua, Jaminan Kematian, serta santunan berkala. Sedangkan Jaminan Pemeliharaan Kesehatan dan Jaminan Kecelakaan Kerja tidak dibayarkan oleh pihak BPJS Ketenagakerjaan dikarenakan masih terdapatnya tunggakan iuran yang belum dibayarkan oleh pihak perusahan PT. Prakarsa Tani Sejati, yang mana hal tersebut merupakan aturan dari BPJS Ketenagakerjaan jika terdapat tunggakan iuran dari pihak perusahaan, dan terdapat beberapa tenaga kerja yang belum terdaftar sebagai peserta BPJS Ketenagakerjaan, maka untuk proses pengajuan klaim menunggu tunggakan iuran dibayarkan terlebih dahulu, kemudian barulah bisa dilakukan pencairan klaim santunan jaminan.

\section{Daftar pustaka}

Mulijanto. 2002. Asas-Asas Hukum Pidana. Cetakan Ketujuh. Jakarta. Rineka Cipta.

Oktavianus, Boby Chandro. Sistem Jaminan Sosial. www.politik.lipi.go.id. Diakses pada tanggal 12 Maret 2019.

Undang-Undang Republik Indonesia Nomor 24 Tahun 2011 tentang Badan Penyelenggara Jaminan Sosial Ketenagakerjaan.

Undang-Undang Republik Indonesia Nomor 3 Tahun 1992 Tentang Jaminan Sosial Tenagakerja.

Wijaya, Andika. 2017. Hukum Jaminan Sosial Indonesia. Jakarta. Sinar Grafika. 